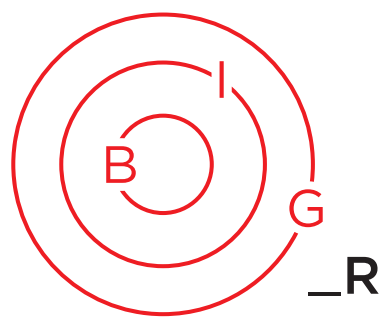

ARTICLE SPECIAL SECTION

\title{
Rohingya Refugee Movement in Bangladesh: Insiders and Outsiders in Strengthening and Weakening of Borders
}

\author{
Sariful Islam *
}

This paper examines the role insiders and outsiders play directly and indirectly in strengthening both territorial and psychological borders. At the same time, it also investigates how they undermine the existing boundaries of difference; in other words, how they weaken borders. This study understands 'borders' as both physical and cultural boundaries or visible and invisible boundaries of (re)producing and (re)ordering "us" versus "them" or insiders and outsiders. The conceptual framework developed by Azmeary Ferdoush (2017) has been employed to investigate the role of insiders and outsiders in strengthening and weakening borders. The Rohingya movement to Bangladesh case study is used to examine the paradoxical affects that both insiders and outsiders have on borders. This study aims to contribute the existing literature by explaining how borders are (re)produced and (re)shaped with the interaction of both the insiders and outsiders, with a specific focus on the implications of the refugee movement on border-making.

Key Words: Border, Refugee Movement, Rohingya Refugee, Bangladesh.

\section{Introduction}

Borders are intended to keep aliens or foreigners out or to restrict their movement. It is traditionally thought that insiders, particularly the state actors, play the main role of border making and bordering. With the emergence of critical perspectives, the concept of the border gets widened, which includes both the physical and psychological borders. Critical scholarship has also pointed out the role the people of a country play in border-making (Rumford 2006; 2008). However, literature on the role of "others" remains scant despite the indispensable role they play in making, strengthening, and weakening the borders. This paper explains how insiders and outsiders play both direct and indirect roles in strengthening territorial and mental borders. At the same time, it also investigates how they undermine the existing boundaries of difference; in other words, how they weaken the borders.

This study aims to contribute the existing literature by explaining how the borders are (re)produced and (re)shaped with the interaction of both the insiders and outsiders. It also provides an empirical analysis of the role of both insiders and outsiders in (re)making the borders, with a specific reference to the Rohingya refugee movement. The 'insiders' in this paper are the state actors and the local people while the refugees are the outsiders. The borders are in a constant process of (re)making with the movement of the refugees.

* Sariful Islam, Doctoral Candidate at the Department of International Relations, South Asian University, New Delhi, India. Email: sarifmcjdu@gmail.com 
This paper brings the case of the Rohingya refugee movement and argues that the borders are not static but dynamic, and the borders are made by the actions and perceptions of relevant actors.

This paper has four sections. The first section discusses the conceptual framework and research methodology. The conceptual framework draws insights from border studies literature in general but mainly uses the conceptual approach developed by Azmeary Ferdoush (2017). As the paper is about understanding the role of the insiders and the outsiders in (re)shaping the borders, Ferdoush's approach of "seeing borders through the lens of structuration" (Ferdoush 2017) helps us to understand the constitutive role of structure and agent in (re)making the border. This section also briefly deals with the concept of agency by drawing insights from critical scholarship (Chatterjee 2013; Scott 1985, 2009; Stern, Hellberg \& Hansson 2015). It concludes by briefly discussing the data sources for this research. The second section traces Bangladesh's colonial legacy of ordering foreigners through bordering mechanisms and new developments. This discussion is required to understand the trajectory of border-making between Bangladesh and Burma/Myanmar and the implication of the Rohingya issue on border management. The third section examines how both the insiders and outsiders play a role in strengthening and weakening these borders. Both hard and soft measures are at the hand of the insiders. Meanwhile, everyday survival mechanisms make the Rohingya refugees choose between sometimes following the border-making strategies and policies of Bangladesh and sometimes avoiding and resisting the same strategies and policies. The fourth section presents the concluding remark.

\section{Section I: Theoretical and Methodological Framework}

This study recognizes that borders are constitutively constructed and that both territorial and psychological borders are constructed and performed by relevant actors. The concept of a border is no longer an easy one to define. With the expansion of scholarship on borders and boundaries, the understanding of borders has now become vague, obscured (Johnson and Jones 2011), and more complex (Johnson \& Jones 2011; Paasi 2009). While in a traditional geographical sense, borders used to be denoted territorial boundaries that differentiated one state from another. The concept of a border is no longer attached with the geographical demarcation alone (Sendhardt 2014). Borders are now increasingly conceptualized as "discourses and practices" (Pfoser 2020,2 ). The constructivist perspective focuses "beyond the visible, material, and seemingly objective manifestations of borders" (Sendhart 2014) while considering borders as a "dynamic cultural process" (Sendhart 2014, 26, quoting Paasi 2003). This perspective does not deny the concrete form of the border but centres on "social practices and discourses" in understanding the borders. To constructivist scholars, borders are a "dynamic cultural process" as they are produced and reproduced through everyday practices, policies, and discourses. According to Newman and Paasi (1998), borders are dynamic as they rise and fall, or the construction and deconstruction of boundaries go with the progress of human civilization and social transformation (193).

As our understanding of borders expands, we understand that borders exist both inside and outside of a country in various forms and modes. Borders now exist at the "edges" of territories as well as through innumerable "societal practices and discourses" (Allen 2011, 287, quoting Paasi 2009). According to Balibar, "borders are everywhere" (as cited in Johnson \& Jones 2011, 61). Boundaries might exist visibly or invisibly, in their physical or symbolic form, or as both; sometimes the material forms can be visible while sometimes the symbolic or both can be simultaneously (Newman \& Paasi 1998, 194). To David Newman and Anssi Paasi (1998), "state boundaries [border] are equally social, political and discursive constructs, not just static naturalized categories located between states" (187).

In alignment with the constructivist perspective, the border is also seen as an act of performance. Johnson and Jones (2011) suggest, "Borders are enacted, materialized, and performed in a variety of ways" (61). Drawing on the work of Judith Butler, Mark Salter suggests that border is performative. The performance embodies the articulation and re-articulation of something through "stylized repetition of acts" (Salter 2011, 66). The border is performed through formal policies of demarcation, practical exercising of including and excluding, and discursively articulating and rearticulating the meaning of border in popular realm. Different actors such as governments, citizens, and other agents perform the border in various ways (Salter 2011, 66).

Since this study understands borders as both physical and cultural boundaries, or visible and invisible boundaries of (re)producing and (re)orderning "us" versus "them" or insiders and outsiders, the conceptual framework developed by Azmeary Ferdoush would be appropriate to adopt to investigate the role of the insiders and outsiders in strengthening and weakening the borders. Ferdoush (2017) has developed the conceptual approach of "seeing borders through the lens of structuration" by drawing Anthony Giddens' theory of structuration. He sees borders as the "edges of structure" and the state as the "structure" (Ferdoush 2017, 8).

Ferdoush's approach does not privilege either the structure (state) nor the agents (individual actors) solely; instead, he accords their significance in equal measure in (re)producing, (re)shaping, and influencing borders and bordering practices (Ferdoush 2017, 2). Both citizens and non-citizens are agents in addition to the state actors that play a role on the border (Ferdous 2017, 5). According 
to Ferdoush (2017), as borders are in a "constant state of becoming," emphasis should be given both to the state and people (4). Ferdoush's makes the conceptual framework easy to understand by breaking the argument down into four:

1. structural factors play a role in determining the characteristics of a particular border;

2. actors, including the borderlanders, border crossers, border guards, and so on are reflexive human beings who reflect upon these structural factors based on their socio-political status, economic condition and positionality, and cultural background;

3. this reflection influences the way actors choose to interact with a given border within the limits of the rules and resources to which s/he is entitled;

4. these rules, resources, actors, and structural factors with their constant (inter)action give birth to localized totalities with the greatest time-space expansion become institutionalised and supply the rules and resources for further interaction between the structure and the actor (Ferdoush 2017, 5).

The first two points accord agency to both the state (as structure) and to non-state actors (as agents). Along with an emphasis on the state actors, the focus on the non-state actors, in other words, the ordinary people, including citizens and non-citizens, play their part in making and remaking the border. Chris Rumford (2008) conceptualizes the role of the people in making and remaking the border as "borderwork" (2). Rumford (2006) notes that "debordering and rebordering accompany each other" and borders do not remain the same or fixed (157). Bordering, debordering, and rebordering, according to Rumford, are no longer the exclusive business of the state. The ordinary people, the citizens, are also in the business along with the state actors. Similarly, VaughanWilliams also notes down the role of citizens in working as deputies of state actors in borderwork (as cited in Johnson and Jones 2014, 5). Johnson and Jones (2014) termed the actors that are not state actors but play their part in border making and strengthening the border as "non-traditional actors" (6). These actors (re)produce border through their everyday life experiences. Borders exists through everyday interactions with the "other." However, the non-traditional actors or the local actors, mainly the people, might not always be on equal terms with the central government or state actors. As Ferdoush suggests, some factors, namely cultural or ethnic factors, religious ties, and cross-border ties, sometimes play a positive or negative role between the local populations and the refugees, the "outsiders."

It is required to note that there exists a difference of power and resources between the state and the people. Traditionally, since the state avails more resources, it might have more power to influence and make a difference in producing and reproducing the borders and borderwork. The second point in Ferdous's argument highlights the everyday activities of the actors who work within and sometimes outside of the already settled rules and policies and (re)produce or (re)shape the border. Actors' perception of the border and their action is determined by three significant factors: socio-political characteristics, economic conditions, and cultural background (Ferdous 2017, 9). Ferdous (2017) terms these actors as "reflexive actors" as the combination of these three factors influence their perception and actions while their day-to-day actions influence the bordering process (9). According to his approach, neither the state (structure) nor the agents are static; instead, they are dynamic, evolving, and interactional. As this is so, the border and bordering process could be understood as constitutive. The insiders and outsiders are part and parcel of the production of borders. In the words of Nick Vaughan Williams (2009), "Indeed, borders are perhaps even constitutive of political life. Borders are inherent to logics of inside and outside, practices of inclusion and exclusion, and questions about identity and difference" (1). The existence of a border is realized and materialized with the acceptance of the notion of the border as a line of demarcation-both territorial and psychological-and the everyday exercise of the border. With their acceptance and resistance, both the insiders and the outsiders (re)produce and (re)shape borders. It is not that the border only excludes or permits foreigners. Through the border, state actors and citizens maintain relations to the foreigners. The existence of insiders and outsiders is relational, and the one cannot exist without the other.

The insiders in this paper are the Bangladesh's state actors and the local people while the outsiders are the Rohingya refugees. It is now pertinent to unpack the concept of agency and delineate its usage for this paper. It is generally presumed that agency is "the capability" of the subjects/actors of "doing things" (Ferdoush 2017, 8). However, the term agency "means and does different things" from one scholar to another (Stern, Hellberg \& Hansson 2015, 11). While it is, for some scholars, the capability or doing the actions, it is, for others, the resistance of the governed subjects to the actions taken by the rulers or the dominant group. It could also mean the wilful inaction of some actors. Even "carefully selected strategies of silence and muted voice" are considered agency (Thomson 2013, 589).

Political anthropologist James C. Scott (1985) observes that the people at the margin of the hierarchical structure manipulate the existing status quo for their interest. It is not that they are not aware about their position in the society or the exploitation they are going through; it is their way of compromising and demanding from the powerful class within the existing system. In his early work Scott (1985) notes how the "everyday resistance" in which the subordinate group neither go for "outright collective defiance nor rebellion" (27). In his more recent work Scott (2009) discusses the resistance to the state apparatus by fleeing from the reach of the state while noting the adaptive strategies "to take advantage of favourable developments at the political center and to shield themselves from the worst effects of turmoil" 
(332). Political theorist Partha Chatterjee (2013) observes how some marginal groups demand their rights within the existing state structure, with some groups succeeding and some not. The marginal group might need to go for bending or stretching the rules (Chatterjee 2013, 66). We can draw from both Scott and Chatterjee that the marginal groups act everyday accordingly to their survival interest and contextual manner. Their cognizance of following the rules, norms, and policies of the dominant actor or group in the society or the state varies from context to context and situation to situation. The resistance to the dominant rules and norms that are discriminatory to them remains mostly latent and symbolic but spark out when the limit of toleration is crossed. In a similar line, even in a more clearly articulated way and also keeping the room for understanding the agency in broad way, Stina Hansson and Sofie Hellberg (2015) include "both the refusal and the acceptance of the rules of governing" in defining agency (29).

In this study, the capability of doing as per the pursuance of state is agency for the state apparatus of Bangladesh. The agency for the people of Bangladesh is their wilful action and the cultural production against as well as in sympathizing with the Rohingya refugees. The Rohingya refugees are considered the marginal group and hence, their agency is understood in a vague way. Their resistance to Bangladesh's action and policies, as well as their acceptance and the adaptation to the same, are understood as agency. The agency for the Rohingya refugees is part of their everyday survival strategy whereas the agency of the Bangladeshi state apparatus is to act upon the outsiders. It is thus the state actors have much leverage than the outsiders, i.e., the Rohingya refugees, in (re)making and (re)shaping the borders.

\section{Research Methodology}

The Rohingya movement to Bangladesh is the case study for examining the paradoxical characteristics of the strengthening and weakening of the borders through the actions of both "insiders" and "outsiders". The data for this research is primarily collected from secondary sources. Besides consulting related academic books, articles, and Bangladesh's government's policy reports, an archival study of newspapers was also done to collect data for this study.

\section{Section II: Rohingya Issue and Bangladesh- Myanmar Border-A Brief Note on Colonial Legacies of Border making to Present Time}

As many other South Asian countries inherited the British mode of governance, so did Bangladesh, though the latter was borne out of a second partition in 1971 from Pakistan which was created in 1947 by a tragic partition of British India. British rule converted frontiers to borderlands, and the 1947 partition changed them to borders (Banerjee 2010, xxxiv). The borders during the British rule were largely unprotected, unguarded, and unfenced. It was the state's coercive machinery inside the controlled territories that worked to find out the outsiders (Banerjee 2010). To make the drawn border alive, British rulers initiated and invented some measures. Through legislative Acts such as the Foreigners Act of 1864, Aliens Restriction Acts of 1914 and 1919, and the Passport Act of 1920, as well as administrative practices such as population census, the British rule enrooted the practice of "othering" and thus ordering the movement of the people, not to mention foreigners, was governmentalized. However, it was judicious towards the categories of alien/foreign and deported them (Banerjee 2010). It is also notable that the British allowed the Arakanese refugees to integrate with the local society. In some cases, the British rulers even sponsored their resettlement. For example, Hiram Cox, a mid-ranked government official, was appointed to supervise the resettlement of the Arakanese refugees in Cox's Bazar area in the 1780s (Chakraborty 1984).

The dissecting of British India into different parts had split a community into two parts and undermined the cultural, ethnic, language commonalities. The countries that emerged with the abolition of British rule still bear the scars of dissection. Though post-colonial South Asian countries have been carrying out nation-building projects forward over time, it does not get away from the cross-border ethnic or cultural connectivity among the people or the people's movement across borders. Post-colonial South Asian countries inherited some of the governance technologies from their colonial rulers; nonetheless, the nature of the border and border management strategies are qualitatively different from the British rule. The border demarcation with the neighbouring countries during the British rule was a result of either war, diplomatic negotiation, or both (Tripathi \& Chaturvedi 2020). During British rule, borders were loosely demarcated but were not decorated with the high presence of border guards and fences. The current India-Nepal border came into existence after the 1814-1816 war and subsequent agreement between British India and the Kingdom of Nepal is an example of identifying the borders but keeping flexible. The policing at the borders and fencing up are getting to new levels as time passes. For instance, the highly securitized fencing and the presence of border security forces along borders of Bangladesh and Pakistan by India informs qualitative changes in border management in post-coIonial South Asia. Moreover, there has been a rise of hard measure border management strategies in South Asia in recent decades. India has already erected fences along 3123 kilometers out of 4096 kilometers land border with Bangladesh (GOI 2021). The government of India has adopted a multi-pronged approach which includes the construction of fences, uninterrupted surveillance, and the installation of Hi-Tech surveillance equipment along the Bangladesh border (Business Standard March 25, 2021). 
Borders in Globalization Review | Volume 3 | Issue 1 | Fall/Winter 2021

Islam, "Rohingya Refugee Movement in Bangladesh: Insiders and Outsiders..."

Bangladesh inherited its borders from Pakistan when the former achieved liberation after a bloody war in 1971. As Bangladesh inherited a governance system from Britain and Pakistan, it does also inherit some cross-border issues with neighboring countries. Amongst many, the movement of the Rohingya is one. Under British rule, the flow of people, including the Arakanese Muslims to eastern part of Bengal (present-day Bangladesh'1), was not a bone of contention as both the territories were ruled by the British. However, prior to the British's conquering of Arakan (Rakhine) and subsequently Burma, eastern Bengal (present-day Bangladesh) used to a place for the Arakanenese refugees to take shelter in order to escape the oppression of Burmese rulers (Chakraborty 1984). During the British rule, people from both sides crossed borders for various purposes including employment. Sometimes, the administration resettled people as per their interests of governance, cultivation and development projects (Akhanda 2018; Chakraborty 1984). During World War II, due to the advancement of the Japanese forces, some thousands of Muslims who supported the British crossed over to eastern Bengal (Jilani 1999; Pandey 2017). After the end of colonial rule, the boundary line came into existence between the newly emerged East Pakistan (present-day Bangladesh) and Burma (present-day Myanmar). However, the porousness of the border remained in large extent. The Pakistani government had to deal with the refugees coming from Burma in 1948 and 1958 (Bahar 2012; Pandey 2017). The effort of the Pakistani government of sending back the refugees and Burmese government agreement to take back refugees came in 1958 signified the "otherness" of the refugees in post-colonial South Asian neighbors. Seeing refugees as "others" flowed from the Pakistan era into the independent Bangladesh in a more rigid form. The borders were drawn between present-day Bangladesh and Myanmar by separating the latter (erstwhile Burma) from British India in 1937 based on the India Act of 1935. Bangladesh and Myanmar share both land and maritime borders of a length of 314.20 kilometres. The first large scale Rohingya refugee movement in 1978 initiated the land border issue between Bangladesh and Myanmar and subsequently an agreement was reached to demarcate the land border (The Bangladesh Observer August 2, 1978). After the second wave in 1991-1992, both countries signed the "Demarcation of the Land Section of the Boundary North of the Naaf River" (Uddin 2014, 9). In its part of the land border, Myanmar has already erected barbed wire on almost 80 percent area (Xinhua March $10,2019)$. Being an economically developing country and having a lack of willingness, Bangladesh did not follow the path of Myanmar until recently.

The Rohingya refugee movements and other related illegal movements and activities bring border security for discussion time and again. The movement of refugees and the activities that are by-product of the refugee movement such as cross-border drug and arms smuggling and insurgent activities have made Bangladesh and Burma feel the need to demarcate and secure their borders. State centric security scholarship and the government documents contend that the Rohingya refugee issue is hampering the stability and security in bordering areas and impeding the cooperation between two countries (Uddin 2014). The Rohingya refugee crisis has pushed Bangladesh to consider its border security to a greater extent both on the borderline and inside the country.

While the Bangladesh government has been taking measures to maintain the physical borders, the cultural production of borders has also started with the inception of Bangladesh as an independent country. The nation-building project of Bangladesh is primarily based on secular cultural Bengali identity (Bjornberg 2016). Sometimes the nationalism gets an overtone of Muslimness. The oscillation between cultural ethnocentrism and religious identity shifts as the main political parties in power change (Majumder 2016). Like most nation-states, Bangladesh has also been pursuing an exclusionary nationalism that even sometimes pushes the non-Bengali tribal community to the line of exclusion. In the initial days of the newly independent Bangladesh, the indigenous communities of the Chittagong Hill Tracts were asked to change their identity and convert to Bengali (Chakma 2016; Mohsin 1997). For the Rohingya people, the ethnic gap presents itself as a gulf in the imagination of the Bangladeshi Bengalis (Bjornberg 2016; Farzana 2017). The religious similarity plays a subtle role in bringing two communities together but does not stand firm in the territorially confined imagination of a nation-state (Farzana 2017).

The exclusionary nation-building imagination and the practices do not allow the borders to be dismantled but rather they are sustained. However, the borders sometimes are strengthened and weakened. Bangladesh has taken steps combining both violent/ hard and non-violent/soft measures. The measures are hard that make the bodies of the physical border crosser are the sites of imposing both the instrumental and abstract technologies that obstruct the entry or at least force to follow some procedure to enter from one side of the border to another. The hard measures can be violent as well (Jones 2016). The soft measures are the exercises that are culturally produced. It includes the narratives of making "other."

\section{Section III: Agency of Bangladesh-Use of Hard Measures in Strengthening Border}

Bangladesh partially uses coercive and productive power to strengthen the borders and borderwork or embolden the "identity/difference" that makes the Rohingya refugees "outsiders" or "others" (Connolly, 1991). Bangladesh continuously struggles in maintaining 
the sanctity of the borders amid the increased inflow of the Rohingya. Both hard and soft borders are in consultation with each other. The Rohingya inflow in Bangladesh has been pushing Bangladesh to strengthen the physical borders and increase the border-making practices in the borderland. The first large scale influx of refugees in 1970s had pushed Bangladesh to bring the issue of border demarcation at the table of discussion with Burma as discussed above. Stringent action was not in place at that time. However, it is alleged that the repatriation of some 200,000 did not happen without coercive measures. Though the government in Bangladesh-inside and outside of the country-was propagating to provide shelter to the Rohingya refugees as part of the religious obligation as a Muslim country, it was not ready to provide shelter to the refugees permanently (Islam 2022). Since the second major influx in 1991-1992, Bangladesh has been following restrictive border polices and measures in regards to the movement of the Rohingya; the restrictions became more visible from 2009 onward. The policies are multi-faceted: restrictive entry, temporary shelter, and restricted rights (Uddin 2020; Islam 2019). It has increased security on the borders due to the increased movement of the Rohingya refugees.

The movement of the Rohingya has made Bangladesh realize the urgency of building up military forces at the borders and increase surveillance and patrolling. The active military response of Bangladesh to the military build-up of Myanmar during the refugee influxes, particularly in 1991-1992 and 2017, suggests that Bangladesh shows its determination of protecting the borders and, thus, asserts its sovereign authority. With a defensive approach to protecting, Bangladesh actively maintains the status of the existing border. From 2009 onwards, Bangladesh has increased surveillance and patrolling along the borders and adopted a policy of detention and push back of Rohingya. For the first time in 2009, police and the Border Guard Bangladesh (BGB) were "actively involved in rounding up unregistered Rohingya at their workplace, along roads, on buses and in their homes, simultaneously in all sub-districts where Rohingya have settled" (Lewa 2010, 3). Though this policy saw a setback during the 2017 influx, it started to go back to the previous position a few months after the 2017 influx. After each massive influx, Bangladesh upgraded some technologies adopted in previous times and added some new ones in strengthening the borders. The Bangladesh government decided to erect a barbed-wire fence along with the Myanmar border "to prevent illegal migration of Rohingya [M]uslims" (Chowdhury 2013). In regards to this initiative, the first of its kind in Bangladesh since its independence, Bangladesh's Home Minister Mohiuddin Khan Alamgir informed the Parliament in June 2013, "we have approved, in principle, the proposal to construct a barbed-wire [fence] along the Bangladesh-Myanmar border, set up searchlights, build watchtowers and 21 new outposts to improve border surveillance" (Chowdhury 2013). He also informed that his government's enhanced patrolling at the border foiled the attempt by the Rohingya refugees to enter Bangladesh (Chowdhury, 2013). In 2013, for the first time, Bangladesh approved a "Strategy Paper on Addressing the Issue of Myanmar Refugees and Undocumented Myanmar Nationals in Bangladesh" (Abrar 21 June 2014). This strategy paper aimed to: reinforce vigilance along the Bangladesh-Myanmar border in order to stop the intrusion of Rohingya refugees, enlist the undocumented Rohingya refugees, provide basic amenities to the documented individuals, and create international pressure on Myanmar to take its nationals back (RohingyaBlogger).

As the days go on, the Bangladesh government continues to beef up security measures at the borders and take precautionary measures. The government's plan of fencing the border came to light again in 2016. Director-General of BGB Major General Aziz Ahmed said that the government has already approved a project for erecting a 282-kilometer barbed wire fence along both the India and Myanmar border, which will begin with the fencing on the Myanmar border (Bhat 2016; The Economic Times 12 July 2018). According to Bradnock (2016), "The fencing of the borders has been designed to limit both refugee movement and politically motivated infiltration, but the issue remains alive and unresolved" (p.170). After the inauguration of a border outpost (BOP) in Saint Martin's Island on September 24, 2019, BGB chief Shafinul Islam said that the barbed wire fencing along the Myanmar border would start soon. Since the 2017 Rohingya refugee influx, the number of BGB members have been increased along the border with Myanmar has been increased significantly (Zaman January 19, 2019). It is now become a short notice issue for the Bangladesh authority to deploy para-millitary forces at the border if something happens in Myanmar that might force the Rohingya to move out. For instance, just after the coup in Myanmar in the early February 2021, Bangladesh stepped up the security along its border with Myanmar (Business Standard February 4, 2021).

The border is not now confined only to the territorial boundary that demarcates from other countries. Inside a country, through "ordering" and the making of "others", bordering takes place. This makes the border keep the "outsider" out and identify them as "other" inside the country. The presence of outsiders inside the country provides an impetus for a host country to invent or employ technologies, such as documentation, encampment, and legal action, or even the erection of visible and invisible walls separating them as "others". The practice of the encampment of Rohingya refugees has become more normal after each influx and it has become stricter. During the first influx in 1978, the Rohingya refugees were put into 13 makeshift camps, and after repatriation, these camps were dismantled. 
During the second influx, more than 20 camps were set up for the Rohingya. Before the repatriation started, there was less restriction on their movement. The restrictions came stringently after 1994, which was the cut-off year of allowing the Rohingya refugees in Bangladesh, and at that time, the repatriation was in the pick. Bangladesh thought that providing easy entry to the Rohingya refugees might endanger the repatriation campaign. The repatriation continued till 2005 in several phases, overcoming some hurdles. The Rohingya refugees who were not repatriated were encamped in two officially designated refugee camps-Kutupalong in Ukhiya and Nayapara in Teknaf (Uddin, 2019). Refugees staying in these camps face restrictions on the right to movements, works, and education, albeit these are different kinds or restrictions as compared to the same in the Rakhine state of Myanmar (Islam, 2019; Uddin, 2020).

The inflow of Rohingya in 2017 has surpassed all previous instances, and even the number of refugees entered is more than double of first and second influx combined. Bangladesh is now hosting more than one million Rohingya including 740,000 newly-arrived Rohingya. They are kept in 34 newly built temporary camps (Uddin, 2019). The camps that have been set up after the 2017 influx are under more surveillance. The Rohingya refugees are subject to several restrictions regarding their movement, education, and work (both inside and outside of the camps). They can go outside the camps only for health or other emergency reasons, subject to prior permission from government officials. Their movements are strictly regulated and under surveillance. There are para-military and police check posts around the camps (Ashraf 2021; Islam 2019). These restrictions have been implemented on a broader scale than they were previously. The government has found Rohingya scattered in different districts, particularly in the Chittagong Hill Tracts (CHTs), which was not there before the 2017 influx. It was an open secret that the Rohingya were living outside of designated camps, but it was not like it is today where the government wants all the Rohingya to be inside the camps. Providing shelter to the Rohingya outside of the camps is now treated as a punishable offense. In a few cases, shelter providers have been detained (Dhaka Tribune April 28, 2019).

To make surveillance easier and more convenient, the Bangladeshi government has planned to erect a barbed-wire fence around the Rohingya camps to "ensure security inside the camps" and stop them move out to other parts of the country and install watchtowers and CCTV cameras for monitoring the refugees (New Age September 26, 2019). The Bangladeshi government also has a plan to form a special police unit for maintaining law and order in the camps (New Age November 26, 2019). It has recently decided to control mobile phone communication in the refugee camps. Though the government made this decision in September 2017, it came again to light when the Rohingya refugees staged a grand rally that consisted of more than one hundred thousand people marking the two years of their exodus from Myanmar (New Age September 3, 2019; New Age August 25, 2019). According to the government's policy, they can get telecom services through public call offices installed at the camps by TeleTalk, a state-owned mobile phone operator but Rohingya are not officially allowed to use mobile phones (New Age September 3, 2019). Home Minister Asaduzzaman Khan warned that Rohingya would face legal action if they defy the order of not using mobile phones (New Age September 14, 2019). It is reported that snapping the cellular connection in the camps aims to curb crimes in the camps amongst others (New Age September 3, 2019).

An intricate technology related to the encampment of the refugees is documentation/registration. The Rohingya refugees were registered in 1978 and 1991-1992 as "refugees". That time identity cards given to them were a most likely traditional ones. Only 34,000 registered Rohingya have refugee status. Rohingyas that came in before the 2017 influx and are not considered "refugees". They are enlisted as "forcibly displaced Myanmar nationals" (Uddin 2019). The Bangladeshi government has taken the initiative, with a collaboration of UNHCR, to bring the Rohingya staying in Bangladesh under biometric registration. The practice of biometric registration was introduced for the first time in June 2018. Between then and August 2019, more than 500,000 Rohingya had been given biometric identity cards. UNHCR spokesperson Andrej Mahecic says, "this is the first ID, a first proof of identity that they have" (UN News August 9, 2019, para 11). These identity cards are given only to refugees who are over the age of 12 and they "carry unique biometric data that includes fingerprints and iris scans" as well as digital photographs. These cards are not considered "citizenship documents for Myanmar" nor are they permit documents for movement or work in Bangladesh (UN News August 9, 2019, para 11). UN Spokesperson Mahecic clarifies the purpose of giving these smart identity cards saying, "these cards are basically their [Rohingya] registration...They regulate their stay in Bangladesh" (UN News August 9, 2019, para 12).

The refugee community knowingly or unknowingly gives their consent to formalize their "alien" identity. When the majority of Rohingya were registering and accepting bio-metric identity cards, they were categorized as "Myanmar nationals". This data registration is helpful for the host government, as well as national, intergovernmental, and international organizations for providing basic amenities, services, and legal protection. However, it is not out of implication for creating a border. This governmentalized technology needs to be seen as something that creates a psychological border and enhances the existing physical border 
by referring the entrants as "foreigners" or "refugees". The body of the refugees becomes the site of exercising the administrative power of the governments or other organizations working with the governments. Btihaj Ajana rightly defines biometrics as "a technology of biopower whereby the body and life itself are the subject of modalities of control, regimes of truth and techniques of sorting and categorization" (Ajana 2013, 4). It is important to say that the Rohingya staying in Bangladesh that have registered are convinced by the logic of getting basic amenities and shelter. However, the latent purpose of the biometric registration is to identify the "outsiders" and then track and control their movement. They are not only easily identifiable and regulated but also they, by default, become "others" in Bangladesh through the process of registration (Oh 2017). A difference in identity with the host community emerges through such administrative practice. Su-Ann Oh (2017) notes, "Bio-metric registration is another way in which refugee bodies may be classified as other" (3). These registration cards produce an identity of the Rohingya who are only allowed to stay at the designated camp. Along with physical structures of the camps and the security vigilance of the security forces in and out the camps, the documenting process creates a demarcation line for the refugees to stay or not to stay.

Bangladesh has been carrying out such measures without any clear legal framework or legislation relating to the refugees, particularly the Rohingya refugees. In the absence of a particular legal framework to deal with the refugee issues, Bangladesh utilizes its state machinery (such as courts and already existing law) and applies it to foreign nationals. Existing domestic legislation or judicial verdicts are being used to maintain the borderline between the Bangladeshi and the Rohingya. To stop local integration, the High Court of Bangladesh in 2014 banned the intermarriage of local Bengali and Rohingya. The Supreme Court upheld the verdict of the High Court in 2018 making intermarriage a punishable offense (BBC January 8, 2018). It has also banned education in Bangla in the camps while the Rohingya children are not allowed to take formal education in any Bangladeshi school (Mayberry December 13, 2018; HRW 2019).

\section{Agency of Bangladesh: Soft Measures in Strengthening Border}

Besides erecting new borders or strengthening the existing ones, state actors play a significant role in producing psychological borders. The Bangladeshi state and non-state actors produce narratives that make the Rohingya refugees "outsiders" that they need to get rid of. The state actors portray the Rohingyas as "trouble-makers" or a "burden", at best, and "elements for security concerns" at the worst (Ashraf 2021; Islam 2019; Islam 2022; Uddin 2020; Yasmin \& Akhter 2020). The local community also plays its part in the same.
The initial hospitality shown to the Rohingya during the influx fades away and turns to hostility over time (Uddin 2012; Uddin 2020; Yasmin \& Akhter 2020). Sometimes the local community produces narratives and use words that demean the Rohingya community. The fact that inter-ethnic marriage is socially ostracized is a bizarre and racial form of discrimination. Before the Supreme Court decision in 2018, the inter-ethnic marriage would be highly discouraged from the local Bengali. The person who marries a Rohingya used to face discrimination in the family and ostracization in the society (Uddin 2020). The local Bengalis think marital association with a Rohingya "jeopardizes the social status, social prestige, generational continuity of a lineage, and the dignity of identity for traditional Bangladeshi" (Uddin 2012, 86; Uddin 2020, 62). Despite cultural and religious similarities, some locals consider the Rohingya as backward (Chowdhury 2019; Islam, 2019) and as people with "no culture...no social norms and values" (Uddin 2020,66). To the locals, the Rohingya refugees have been seen as burdens and trouble makers (Rahman 2010; Yasmin \& Akhter 2019). They are blamed for all sorts of crimes and anti-social activities, though their involvement in such activities is not possible with locals' engagement. A negative perception regarding Rohingya among the locals is so strong that some even use derogatory words such as "animal" or "poisonous snake" and "terrorist" to refer to the character of the Rohingya refugees (Islam 2019).

The Rohingya refugees are dealt initially with "hospitality" but it waned over time (Uddin 2012, 2020). The religious affinity turned dim and the demarcation of difference sprouted out between the locals and the refugees. The locals categorize the Rohingya as "others" and treated them accordingly. That is how a psychological border of demarcation played out between the locals and the Rohingya refugees. Uddin (2020) writes, "in fact, mutual co-existence is also a big problem since both groups, despite religious and linguistic homogeneity, are different in their culture, mode of dealings, and philosophy of life" (76).

\section{Agency of the Rohingya in Strengthening the Borders}

The state plays a vital role in demarking the territorial border and producing an identity of the people living in the particular territory. Though the state actor has "absolute authority in determining interstate population movement on the basis of various markers that often make up their identity", foreigners or outsiders play both direct and indirect role in (re)producing the borders (Chowdhory 2018, 1). The Bangladeshi government has been taking the measures discussed in the previous section in reaction to the refugee movement. The refugee movement pushes the government to pursue several restrictive and governmentalized measures on the borders and inside the country. The Rohingya community has also permitted the "identity/difference" construction of Bangladesh by their active engagement 
in the technologies of border making/strengthening (Connolly 1991). Border and identity are two sides of the same coin (Newman \& Paasi 1998, 194). For Bourdieu, it is to create a border to establish or institute something or, in other words, give something a social definition or identity (cited in Newman \& Paasi 1998, 194). A majority of the Rohingya staying in Bangladesh prefer to call themselves Rohingya and claim their origin in the Rakhine state of Myanmar. In this process, they legitimize the identity/difference and allow bordering/ ordering. Through their perception of being "other" in Bangladesh, the Rohingya community draws a line of difference by themselves. In their daily lives, the Rohingya refugees nurture their identity and continue to transmit the identity markers to the next generation (Farzana 2016; Farzana 2017).

A vast number of Rohingya do not want to stay in Bangladesh if they are given proper rights and surety of life security and safety back in their homeland Myanmar (Sengupta 2020). Despite being officially stateless people in Myanmar, the Rohingya feel a strong belonging to the motherland of Myanmar (Sengupta 2020). They do not consider themselves as people who belongs to Bangladesh. They maintain a distance line, a space of difference. Through their claim of belonging to Myanmar and the inter-generational transition of the ethnic Rohingya identity, they enhance the (re)constructing a notion of "we" - the Rohingya - and "they"-Bangladeshi. Thus, their perception of "otherness" works as a complement to the efforts of the Bangladeshi government and the Bangladeshi people who make the distinction. Myanmar's exclusionary state-building project and denial of the existence of the Rohingya ethnicity, and Bangladesh's unwillingness to accommodate the Rohingya refugees as citizens have made the Rohingya identity strong and reasserted (Farzana 2016; Farzana 2017, Mohsin 2019).

The Weakening of the Border(s): All Actors Play Their Part

As Bangladesh's state apparatus, local people and the Rohingya, in their own ways, play their part in strengthening both the territorial and psychological borders. They also sometimes undermine the existing borders and they weaken the borders in several ways. On the part of Bangladesh, it is a section of local people to "local state" to highest political sovereign perform in weakening the border (Uddin 2019, p.880). All three groups sometimes share some common factors. The political leadership primarily considers the domestic sentiments towards the Rohingya, political cost-benefit calculation, and international factors such as the scale of pressure and promise of assistance and international image building when making decisions regarding the weakening or strengthening of borders (Ashraf 2021, Islam 2019, Islam 2022). The visit of heads of government to the Rohingya refugee camps and their urge to the locals to be sympathetic make the rigidness of the border flexible. For instance, during her visit to the refugees at Cox's Bazar in September 2017, Prime Minister Sheikh Hasina equated the persecution against the Rohingya with the oppression of the Bangladeshi in 1971. She also stated that her government is giving shelter to the Rohingya "on humanitarian grounds, as we are human beings" (The Daily Star September 13, 2017, para: 13). The political leadership presented the suffering of the Rohingya as the rationale for providing shelter. The construction of humanitarian narratives thus lessen downs the restriction at the border at a greater scale and allow the Rohingya to enter.

Along with the political leadership, the "local state" also plays a role in weakening the border. When the higher-ups order them to seal off the border, the para-military forces responsible for stopping the entry of the Rohingya sometimes allow them to enter anyway. The inhuman and miserable suffering of the Rohingya people collapses the walls of restriction inside the border forces of Bangladesh. The rigidness of law takes a flexible application when the state agents at the border are driven by emotional impulse. It has happened during all major influxes. During the initial days of the 2017 influx, a border guard is reported to say, "we have been ordered not to allow Rohingya to enter Bangladesh...But how can I deny shelter to this newborn who is dying from cold?" (France24 August 29, 2017, para: 8-9). France24 has published this comment in a report on August 29, 2017. Until then, Dhaka had not decided to allow the Rohingya to come in. The restriction on the entry of the Rohingya was there through until the end of August (The Daily Star August 29, 2017; Roy and Jinnat August 30, 2017). Some groups entered the Bangladesh border without any problems, while others were detained and pushed back (Roy and Jinnat August 31, 2017). Having been aware of the entry of nearly 20,000 Rohingya by the end of August 2017, some local government officials did not want to officially acknowledge their presence. Roy and Jinnat quoted a top official stationed at Cox's Bazar, saying, "people are coming to Bangladesh like floodwater. My estimation based on reports of different agencies is the number of newly arrived Rohingyas will be 20,000 to 25,000 . But I cannot tell the media about it revealing my identity" (August 30, 2017).

Due to the sympathetic feeling of the security forces at the borders, and despite the official stance of barring the Rohingya from entering, in 2012 several thousand Rohingya came to Bangladesh, and in 2016 less than 100,000. Navine Murshid (2018) got to know "the everyday kindness act" of the border forces while interviewing some of them in 2012 and 2015. Murshid (2018) says that the suffering of the Rohingya compels the border forces to be humane. The act of being humane makes the border forces who are deployed to hinder the attempt of the people of another country to come in allow and weaken the border. In this situation, the territorial border becomes a boundary for shelter 
to the Rohingya, not a territorial bifurcation aimed to keep out the "others".

When border security forces allow the Rohingya to enter, defying the higher-ups' order of stopping them, some other members of "local state" help the Rohingya to undermine borders that is drawn by providing legal documents such as identity card or voter registration card. Besides the members of the state apparatus, the local public representatives allegedly helped the Rohingya people intermingle with the local community and switch their identity, at least in the paper, to Bangladeshi. For their political and material benefits, they dodge the legal system and assist the Rohingya to get the necessary documents required for getting National Identity cards, which is proof of holding the citizenship of Bangladesh. Due to their religious affinity and geographical proximity, the local ordinary people were the first to extend their help to the Rohingya during the influx (Uddin 2015; Islam 2019). The sympathetic response of the locals to the Rohingya could be considered the exposure of the disavowing the attitude of seeing Rohingya as "other" but someone of "us". This "us" feeling that arises from religious affinities and geographical contiguousness, specifically, and humanitarianism, in general, subdue the distinction of citizens versus foreigners. The border of identity collapses here, even if it is for a short time.

While the above discussion highlights the active agency of the Bangladesh's state apparatus and the people of Bangladesh, particularly the locals, through it we can also draw an understanding of the agency of the Rohingya people. They actively influence the initiative and response of both the Bangladeshi people and the government. In contrast to weakening the borders, the Bangladesh government has been exercising all available technologies to stop the entry of the Rohingya. However, the continuous attempt of the Rohingya to enter Bangladesh shows the weakening of the borders. They ingeniously keep trying to enter Bangladesh through different routes if they are pushed back once. Since the second influx, several hundred thousand Rohingya have entered Bangladesh secretly. Once they successfully enter the territory of Bangladesh, they communicate with the others waiting at the other side of the borders to follow their path to come to Bangladesh. They exploit the hilly landscape and thick jungles that make the land border porous between Bangladesh and Myanmar. Once they are inside Bangladesh, many of them try to find out how to mingle with the Bangladeshi society or use Bangladeshi documents to go abroad (Uddin 2020). Uddin observes, "Many, particularly who came three decades ago, now hold Bangladeshi passports and own National Identity Card (NID) and have integrated into local society" (Uddin 2020, p.78). Many have also migrated to Gulf countries using Bangladeshi passports (Uddin 2020). Though earlier it was only at the level of claim by Bangladeshi state apparatus, it has recently come to light that some 55,000 Rohingya residing in Saudi Arabia hold Bangladeshi passports and their passports have expired. Saudi Arabia has pressured Bangladesh to issue new Bangladeshi passports to the Rohingya (Sakib, March 12, 2021).

While some disguise their Rohingya identity and take Bangladeshi identity by forging or by availing documents by illegal means, some stay away from being registered as "Myanmar nationals" in Bangladesh. When the biometric registration process started in 2018, a number of Rohingya resisted being registered. They have preferred to stay undocumented. They see registration as the first step of repatriating them without ensuring their rights and security back in the state of Rakhine in Myanmar and also as a tool to restrict their right to livelihood. Though the unregistered Rohingya people face different sorts of exploitation and discrimination, their resistance response poses a challenge to the state's performance in maintaining the borders. Since the second influx, more than 200,000 unregistered Rohingya have been living outside of the designated camps. Some of them have allegedly intruded on Bangladeshi society by disguising their own ethnic identity. A group of Rohingya who came to Bangladesh in the 1970s and 1990s have now intermingled with the Bengali society. The unofficial integration happens when the Rohingya individuals successfully make the arrangement with the local people and the authority (Cheung 2011, 53). Besides the personal arrangement, according to a report in 2000 Human Rights Watch, cultural and linguistic similarities and shared Muslim faith help the Rohingya people to integrate with the local people in a de facto manner (Cheung 2011, 53). Their conscious choice of hiding their identity helps blur the "citizen" versus "alien" identity. It is possible with the willing blindness of the local people and the authority regarding the identity disguise of the Rohingya refugees.

\section{Section IV: Conclusion}

Both physical and psychological borders are created, enacted, and maintained through boundary drawing or map-making, employing military maneuvers or the performance of the security forces at the border, documenting the people staying inside a country or coming to the country, and social practices of the people in finding similarity/difference. As much as the border is produced through paperwork (i.e. borderdrawing or map-making and documentation), it is just as much a performative act by the government officials and people. The case of the Rohingya refugee movement to Bangladesh shows that the strengthening and weakening of the border is the by-product of the refugee movement as well as it causes. Both "insiders" and "outsiders" play their role in strengthening and weakening the borders. It is thus argued that both the strengthening and weakening of the 
Borders in Globalization Review | Volume 3 | Issue 1 | Fall/Winter 2021

Islam, "Rohingya Refugee Movement in Bangladesh: Insiders and Outsiders..."

borders are constituted. The Bangladesh government apparatus and the common people both play their part in strengthening it as they perceive the Rohingya as "other" from them, as do the Rohingya themselves. The weakening happens when government officials and local citizens consider the Rohingya a fellow human being before a foreigner. However, by their tactful strategies of disguising identity and intruding on mainstream society, the Rohingya also weaken the borders.

However, it needs to be considered that the state apparatus has much more resources and leverage in (re)making and (re)shaping the borders-both physical and psychological. The local people of the host country sometimes work as active agents for the state in strengthening the borders but sometimes they work on weakening the borders. The ground politics and the interests of various sorts implicate the local response in relation to the (re)production of the borders. The drawing of the line of distinction or weakening the border by the outsiders is for their everyday survival and existence. For the Rohingya refugee, the identity claim as Rohingya is related to their existential question. Denying their identity as Rohingya in a foreign land would bring a catastrophic disaster to the group identity, its existence, and their demand to go back to their home country. In such a tricky situation, if some Rohingya refugees escape from the camp and manage to get Bangladeshi documents, it needs to be understood as part of their survival strategy.

\section{Note}

1 The partition of British India created two new states: India and Pakistan. Pakistan had two parts; East and West. The Eastern part is now Bangladesh and West Pakistan is present-day Pakistan

\section{Works Cited}

All hyperlinks last accessed December 2021 unless specified.

Abrar, C. R. 2014. "Government Strategy Paper on Rohingyas: Let Humanitarianism Prevail” The Daily Star (June 21). https://www. thedailystar.net/government-strategy-paper-on-rohingyas-29526

Ajana, Btihaj. 2013. Governing through Biometrics: The Biopolitics of Identity. Hampshire: Palgrave Macmillian.

Akhanda, Mahfuzur Rahman. 2018. Rohingya Somossa O Bangladesh [in Bangla]. Rajshahi: Parilekh.

Allen, John. 2011. “Topological Twists: Power's Shifting Geographies" Dialogues in Human Geography 1(3): 289-298. https://doi.org/10.1177/2043820611421546

Ashraf, A.S.M Ali. 2021. "Humanitarianism, National Security, and the Rohingya Refugee Policy of Bangladesh" Strategic Analysis 45(3): 184-206. https://doi.org/10.1080/09700161.2021.1918953

France24. 2017. "At least 6,000 Rohingya Stranded on Bangladesh Border: Official" (August 29). https://www.france24.com/ en/20170829-least-6000-rohingya-stranded-bangladesh-border-official

Bahar, Abid. 2012. "Burmese Invasion of Arakan and the Rise of Non-Bengali Settlements in Bangladesh: Origin of the Tribes of Chittaging Hill Tract (CHT)-Concluding Part" New Age, (October 23).

Banerjee, Paul. 2010. Borders, Histories, Existence: Gender and Beyond. New Delhi: Sage.

BBC. 2018. "Bangladesh Court Upholds Myanmar Rohingya Marriage Ban" (January 8). https://www.bbc.com/news/ world-asia-42612296

Bhat, Aditya. 2016. "Bangladesh to Construct Fences along India, Myanmar Borders" International Business Times (September 26). https://www.ibtimes.co.in/bangladesh-construct-fences-along-india-myanmar-borders-695355

Bjornberg, Anders. 2016. "Rohingya Territoriality in Myanmar and Bangladesh: Humanitarian Crisis and National Disordering" in Myanmar's Mountain and Maritime Borderscapes: Local Practices, Boundary-Making and Figured Worlds, edited by Su-Ann Oh. Singapore: ISEAS.

Bradnock, Robert W. 2016. The Routledge Atlas of South Asian Affairs. Oxon: Routledge.

Business Standard. 2021. "Bangladesh Ups Security along Myanmar Border to Prevent Influx of Rohingyas" (February 4). https://www.business-standard.com/article/international/ bangladesh-ups-security-along-myanmar-border-to-preventinflux-of-rohingyas-121020302114_1.html

Business Standard. 2021. "Govt to Construct Fence to Stop Infiltration along India-Bangladesh Border" (March 25). https:// www.business-standard.com/article/current-affairs/govt-toconstruct-fence-to-stop-infiltration-along-india-bangladeshborder-121032500286_1.html

Chakma, Bhumitra. 2016. "The CHT and the Peace Process" in Routledge Handbook of Contemporary Bangladesh, edited by Ali Riaz and Sajjadur Rahman. Oxon: Routledge.

Chakraborty, Ratan Lal. 1984. Bangladesh-Burma Relations [in Bangla]. Dhaka: Dhaka University Press.

Chatterjee, Partha. 2013. The Politics of the Governed: Reflections on Popular Politics in Most of the World. Delhi: Permanent Black.

Chowdhory, Nasreen. 2018. Refugees, Citizenship and Belonging in South Asia: Contested Terrains. Singapore: Springer.

Chowdhury, Kamran Reza. 2013. "Dhaka to Build Fence along Myanmar Border" Dhaka Tribune (June 11). https://www. dhakatribune.com/uncategorized/2013/06/11/dhaka-tobuild-fence-along-myanmar-border

Connolly, William E. 1991. Identity/Difference: Democratic Negotiations of Political Paradox. Expanded edition. Minneapolis: University of Minnesota Press.

Dhaka Tribune. 2019. "Over 100 Rohingyas Held across Country in Four Months" (April 28). https://www. dhakatribune.com/bangladesh/rohingya-crisis/2019/04/28/ over-100-rohingyas-held-across-country-in-four-months

Farzana, Kazi Fahmida. 2016. "Life along the Naf Border: Identity Politics of the Rohingya Refugees in Bangladesh" in Myanmar's Mountain and Martime Borderscapes: Local Practices, Boundary-Making and Figured Worlds, edited by Su-Ann Oh. Singapore: ISEAS.

Farzana, Kazi Fahmida. 2017. Memories of Burmese Rohingya Refugees: Contested Identity and Belonging. Singapore: Palgrave Macmillan. 
Ferdous, Azmeary. 2017. "Seeing Borders through the Lens of Structuration: A Theoretical Framework" Geopolitics 23(1): 180-200. https://doi.org/10.1080/14650045.2017.1341406

France24. 2017. "At least 6,000 Rohingya Stranded on Bangladesh Border: Official” (August 29). https://www.france24.com/ en/20170829-least-6000-rohingya-stranded-bangladesh-border-official

Government of India-GOI. 2021. "Rajya Sabha: Unstarred Question No.2437" (March 17). https://www.mha.gov.in/MHA1/Par2017/ pdfs/par2021-pdfs/rs-17032021/2437.pdf

Hansson, Stina and Hellberg, Sofie. 2015. "Power, Freedom and the Agency of Being Governed" in Studying the Agency of Being Governed edited by Stina Hansson, Sofie Hellberg and Maria Stern. Oxon: Routledge.

Human Rights Watch (HRW) . 2019. "Bangladesh: Rohingya Refugee Students Expelled" https://www.hrw.org/news/ 2019/04/02/bangladesh-rohingya-refugee-students-expelled

Islam, Sariful. 2019. "Hosting Rohingya Refugees: Explaining the Factors Influencing Bangaldesh's 'Humanitarian' Response" Master of Philosophy Dissertation, South Asian University.

Islam, Sariful. 2022. "Regime's Interests in Hosting Refugees: Bangladesh's Response to the Rohingya" in Rohingya Refugee Crisis in Myanmar: Ethnic Conflict and Resolution, edited by Kudret Bulbul, Md Nazmul Islam and Md Sajid Khan. Singapore: Palgrave Macmillan.

Jilani, AFK. 1999. The Rohingyas of Arakan: Their Quest for Justice. Ahmed Jilani.

Johnson, Corey and Jones, Reece. 2011. "Rethinking "the border" in border studies" in Interventions on Rethinking 'the Border' in Border Studies, edited by Johnson et al. Political Geography 30(2): 61-69.

Jones, Reece. 2016. Violent Borders: Refugees and the Right to Move. London: Verso.

Lewa, Chris. 2010. "Unregistered Rohingya refugees in Bangladesh: Crackdown, forced displacement and hunger" The Arakan Project. http://www.burmalibrary.org/docs08/ Bangladesh-Crackdown.pdf

Majumder, Shantanu. 2016. "Secularism and anti-Secularism" in Routledge Handbook of Contemporary Bangladesh, edited by Ali Riaz and Sajjadur Rahman. Oxon: Routledge.

Mayberry, K. 2018. "Rohingya Facing 'Lost Generation' of Children Out of School" Al Jazeera (December 13). https://www. aljazeera.com/news/2018/12/rohingya-facing-lost-generation-children-school-181212082048462.html

Mohsin, Amena. 1997. The Politics of Nationalism: The Case of the Chittagong Hill Tracts, Bangladesh. Dhaka: The University Press Limited.

Murshid, Navine. 2018. "Bangladesh copes with the Rohingya crisis by itself" Current History 117(798): 129-134.

Newman, David and Paasi, Anssi. 1998. "Fences and Neighbours in the Postmodern World: Boundary Narratives in Political Geography." Progress in Human Geography 22(2): 186-207.

New Age. 2019. "Rohingas Rally for Rights at Home" (August 25). http://www.newagebd.net/article/82511/ rohingyas-rally-for-rights-at-home

New Age. 2019. "Bangladesh to Snap Telecom Connections of Rohingyas" (September 3). http://www. newagebd.net/article/83348/bangladesh-to-snaptelecom-connections-of-rohingyas

New Age. 2019. "Fences to be Erected around Rohingya Camps:
HM" (September 26). http://www.newagebd.net/article/85763/ fences-to-be-erected-around-rohingya-camps-hm

Oh, Su-Ann. 2017. "Surveillance and Control: The Encampment and Biometric Identification of Rohingya Refugees in Bangladesh" Perspective 93: 1-7. https://www.iseas.edu.sg/wp-content/ uploads/pdfs/ISEAS_Perspective_2017_93.pdf

Paasi, Anssi. 2009. "Bounded $S$ Bounded spaces in a 'borderless world': border studies, power and the anatomy of territory" Journal of Power 2(2): 213-234. https://doi. org/10.1080/17540290903064275

Pandey, Ashutosh. 2017. "Myanmar's Rohingya: A History of Forced Exodues" DW-Deutsche Welle. https://www.dw.com/en/myanmars-rohingya-a-history-of-forced-exoduses/a-40427304

Pfoser, Alena. 2020. "Memory and everyday borderwork: Understanding Border Temporalities" Geopolitics https://doi. org/10.1080/14650045.2020.1801647

RohingyaBlogger. n.d. "Strategy Paper on Addressing the Issue of Myanmar Refugees and Undocumented Myanmar Nationals in Bangladesh". https://pdfcoffee.com/strategy-paper-on-addressing-the-issue-of-myanmar-refugees-and-undocumented-myanmar-nationals-in-bangladesh--pdf-free. html\#rohingyablogger

Roy, Pinaki, and Jinnat, Mohammad Ali. 2017. “Stranded in No Man's Land:Several Thousand Rohingyas from Myanmar Build Makeshift Shelters There" The Daily Star (August 30). https://www. thedailystar.net/frontpage/stranded-no-mans-land-1456003

Roy, Pinaki, and Mohammad Ali Jinnat. 2017. "They Come in Thousands" The Daily Star (August 31). https://www. thedailystar.net/frontpage/rohingya-refugee-crisis-theycome-thousands- 1456507

Rahman, Utpala. 2010. "The Rohingya Refugee: A Security Dilemma for Bangladesh" Journal of Immigrant \& Refugee Studies 8(2): 233-239. https://doi.org/10.1080/15562941003792135

Rumford, Chris. 2006. "Theorizing Borders" European Journal of Social Theory. 9(2): 155-169. DOI: 10.1177/1368431006063330

Rumford, Chris. 2008. "Introduction: Citizens and Borderwork in Europe" Space and Polity 12(1): 1-12. https://doi. org/10.1080/13562570801969333

Sakib, SM Najmus. 2021. "Saudi Arabia Won't Send Rohingya Back to Bangladesh" Anadolu Agency (AA) (March 12). https://www. aa.com.tr/en/middle-east/-saudi-arabia-wont-send-rohingyaback-to-bangladesh/2173654

Salter, Mark. 2011. "Places Everyone! Studying the Performativity of the Border" in Interventions on Rethinking 'the Border' in Border Studies, edited by Corey Johnson, Reece Jones, Anssi Paasi, Louise Amoore, et al. Political Geography 30(2): 61-69.

Scott, James C. 1985. Weapons of the Weak: Everyday Forms of Peasant Resistance. New Haven: Yale University Press.

Scott, James C. 2009. The Art of Not Being Governed: An Anarchist History of Upland Southeast Asia. New Haven: Yale University Press.

Sendhardt, Bastian. 2014. "Border Types and Bordering Processes: A Theoretical Approach to the EU/Polish-Ukrainian Border as a Multi-dimensional Phenomenon" in Borders and Border Regions in Europe: Changes, Challenges and Chances, edited by Arnaud Lechevalier and Jan Wielgohs. Bielefeld: transcript Verlag.

Sengupta, Sucharita. 2020. "Being Stateless and Surviving: The Rohingyas in Camps of Bangladesh" in Citizenship, Nationalism and Refugeehood of Rohingyas in Southern Asia, edited by Nasreen Chowdhory and Biswajit Mohanty. Singapore: Springer. 
Borders in Globalization Review | Volume 3 | Issue 1 | Fall/Winter 2021

Islam, "Rohingya Refugee Movement in Bangladesh: Insiders and Outsiders..."

Stern, Maria., Hellberg, Sofie and Hansson Stina. 2015. "Studying the Agency of Being Governed: An Introduction" in Studying the Agency of Being Governed, edited by Stina Hansson, Sofie Hellberg and Maria Stern. Oxon: Routledge.

The Bangladesh Observer. 1978. "Border Pact with Burma Reached" (August 2).

The Daily Star. 2017. "Provide Shelter, Security to Rohingyas: Khaleda Urges Govt"(August 29). https://www.thedailystar.net/ city/provide-shelter-security-rohingyas-1455655

The Daily Star. 2017. "Take Back All Rohingyas" (September 13). https://www.thedailystar.net/frontpage/ mayanmar-rohingya-refugee-crisis-solution-safe-zone-1460827

The Economic Times. 2018. "Bangladesh to Erect Barbed Wire Fence on Border with India" (July 12). https://economictimes. indiatimes.com/news/defence/bangladesh-to-erect-barbedwire-fence-on-border-with-india/articleshow/54508281. cms?from $=m d r$

Thomson, Susan. 2013. "Agency as Silence and Muted Voice: The Problem-solving Networks of Unaccompanied Young Somali Refugee Women in Eastleigh, Nairobi" Conflict, Security \& Development 13(5): 589-609. https://doi.org/10.1080/1467880 2.2013 .849473

Tripathi, Dhananjay and Chaturvedi, Sanjay. 2020. "South Asia: Boundaries, Borders and Beyond" Journal of Borderlands Studies 35(2): 173-181. https://doi.org/10.1080/08865655.2019.1 669483

Xinhua. 2019. "Myanmar-Bangladesh border fence construction work attacked by ethnic armed group" (March 10). http://www. xinhuanet.com/english/2019-03/10/c_137883675.htm
Uddin, Nasir. 2012. "Of Hosting and Hurting: Crises in Co-existence with Rohingya Refugees in Bangladesh" in To Host or To Hurt: Counter-narratives on Rohingya Refugees Issue in Bangladesh, edited by Nasir Uddin. Dhaka: Institute of Culture \& Development Research

Uddin, Nasir. 2015. "State of Stateless People: The Plight of Rohingya Refugees in Bangladesh" in Slippery Citizenship, edited by Rhoda E. Howard-Hassmann and Margaret WaltonRoberts. Philadelphia: University of Pennsylvania Press.

Uddin, Nasir. 2019. "The State, Vulnerability, and Transborder Movements: The Rohingya People in Myanmar and Bangladesh" in Deterritorialised Identity and Transborder Movement in South Asia, edited by Nasir Uddin and Nasreen Chowdhory. Singapore: Springer.

Uddin, Nasir. 2020. The Rohingya: An Ethnography of 'Subhuman' Life. First edition. New Delhi: Oxford University Press.

Uddin, M Jashim. 2014. "Prospects for Attaining a New Height in Bangladesh-Myanmar Relations: Bangladesh Perspective" BIISS Journal 35(11): 1-22.

UN News. 2019. "More than Half a Million Rohingya in Bangladesh Get ID Cards for First Time: UN Refugee Agency" (August 9). https://news.un.org/en/story/2019/08/1044041

Vaughan-Williams, Nick. 2009. Border Politics: The Limits of Sovereign Power. Edinburgh: Edinburgh University Press.

Yasmin, Lailufar and Akther, Sayeda. 2020. "The Locals and the Rohingyas: Trapped with an Uncertain Future" Asian Journal of Comparative Politics 5(2): 104-120. 